\title{
COCONUT STEM UTILIZATION IN SRI LANKA
}

Ranjith Mahindapala ${ }^{1}$

\section{INTRODUCTION}

In the plantation agriculture in Sri Lanka, coconut occupies the highest area of nearly $420,000 \mathrm{ha}$. It is distributed in all 24 districts. The estate sector ( 8 ha or more) comprises 104,000 ha $(24.7 \%)$ of the area while the balance, 316,000 ha $(75.3 \%)$ is categorized as small holdings (Table 1).

Table 1: Distribution of Ccoonut Holdings and Estates

\begin{tabular}{|c|c|c|c|c|c|c|c|c|c|}
\hline \multirow[t]{2}{*}{ District } & \multicolumn{3}{|c|}{ SMALL HOLDINGS } & \multicolumn{3}{|c|}{ ESTATE } & \multicolumn{3}{|c|}{ TOTAL } \\
\hline & $\begin{array}{l}\text { No of } \\
\text { Holdings }\end{array}$ & $\begin{array}{l}\text { Area } \\
(\mathrm{Ha})\end{array}$ & $\begin{array}{c}\% \\
- \\
\end{array}$ & $\begin{array}{c}\text { No of } \\
\text { Estates }\end{array}$ & $\begin{array}{l}\text { Area } \\
\text { (ha) }\end{array}$ & $\begin{array}{l}\% \\
- \\
\end{array}$ & $\begin{array}{c}\text { No. of } \\
\text { Holdings }\end{array}$ & $\begin{array}{l}\text { Area } \\
(\mathrm{Ha}) \\
\end{array}$ & $\begin{array}{c}\% \\
- \\
\end{array}$ \\
\hline Colombo & 29,360 & 8,668 & 2.7 & 101 & 1,069 & 1.0 & 29,461 & 9,737 & 2.3 \\
\hline Gampaha & 113,230 & 52,302 & 16.6 & 703 & 11,862 & 11.5 & 113,933 & 64,164 & 15.3 \\
\hline Kalutara & 49,400 & 11,408 & 3.6 & 140 & 919 & 0.9 & 49,540 & 12,327 & 2.3 \\
\hline Kandy & 13,010 & 4,670 & 1.5 & 97 & 1,578 & 1.5 & 13,107 & 6,248 & 1.5 \\
\hline Matale & 14,200 & 6,552 & 2.1 & 160 & 2,416 & 2.3 & 14,360 & 8,968 & 2.1 \\
\hline Muara-Eliya & 2,010 & 886 & 0.3 & 05 & $6^{*}$ & 0.0 & 2,015 & 892 & 0.2 \\
\hline Galle & 44,360 & 11,311 & 3.6 & 229 & 1,575 & 1.5 & 44,589 & 12,886 & 3.1 \\
\hline Matara & 46,560 & 14,075 & 4.4 & 251 & 2,430 & 2.4 & 46,811 & 16,505 & 3.9 \\
\hline Hambantota & 31,840 & 18,652 & 5.9 & 157 & 2,157 & 2.1 & 32,997 & 20,809 & 5.0 \\
\hline Jaffna & 13,260 & 4,913 & 1.6 & 204 & 3,956 & 3.8 & 13,464 & 8,869 & 2.1 \\
\hline Mannar & 940 & 1,137 & 0.4 & 13 & 205 & 0.2 & 953 & 1,342 & 0.3 \\
\hline Vavuniya & 750 & 469 & 0.1 & 4 & $18^{*}$ & 0.0 & 754 & 487 & 0.1 \\
\hline Mulativu & 2,110 & 1,509 & 0.5 & 58 & 907 & 0.9 & 2,168 & 2,417 & 0.6 \\
\hline Batticaloa & 8,150 & 2,460 & 0.8 & 104 & 1583 & 1.5 & 8,254 & 4,044 & 1.0 \\
\hline Ampara & 11,550 & 2,428 & 0.8 & 27 & 739 & 0.7 & 11,557 & 3,167 & 0.8 \\
\hline Trincomalee & 4,240 & 1,732 & 0.5 & 19 & 204 & 0.2 & 4,259 & 1,936 & 0.5 \\
\hline Kurunegala & 157,270 & 101,686 & 32.2 & 2,319 & 45,876 & 44.5 & 159,589 & 147,551 & 35.2 \\
\hline Puttalam & 48,550 & 30,586 & 9.7 & 1,235 & 22,586 & 21.9 & 48,785 & 53,182 & 12.7 \\
\hline Anuradhapura & 14,100 & 4,144 & 1.3 & 20 & 160 & 0.2 & 14,120 & 4,304 & 1.0 \\
\hline Polonnaruwa & 7,320 & 2,380 & 0.7 & 8 & 74 & 0.1 & 7,328 & 2,454 & 0.6 \\
\hline Badulla & 1,090 & 571 & 0.2 & 18 & 38 & 0.1 & 1,108 & 609 & 0.1 \\
\hline Moneragala & 11,800 & 3,662 & 1.1 & 10 & 32 & 0.1 & 11,810 & 3,694 & 0.9 \\
\hline Ratnapura & 34,500 & 10,809 & 3.4 & 175 & 973 & 0.9 & 34,675 & 11,782 & 2.8 \\
\hline Kegalle & 49,320 & 19,057 & 6.0 & 223 & 1,764 & 1.7 & 49,543 & 20,820 & 5.0 \\
\hline SRI LANKA & 708,920 & 316,068 & 100.0 & 6,280 & 103,127 & 100 & 715,200 & 419,195 & 100 \\
\hline
\end{tabular}

*) Coconut may be a component in other estates (Coconut Research Institute, Lunuwila, Sri Lanka)

\footnotetext{
${ }^{1}$ Director, Coconut Research Institute, Sri Lanka.
} 
Coconut is a very important commodity in Sri Lanka. It is used traditionally as a component in food, and about $70 \%$ of the production is consumed locally. About $9 \%$ of the total expenditure on food of an average household is spent on coconut, which is the principal source of edible oil and fat. Coconut provides about $22 \%$ of the total intake of calories of an average consumer in Sri Lanka and is only second to rice insofar as intake of calories is concerned (Tillakeratne and Perera, 1981). These data amply demonstrate the importance of coconut in Sri Lanka.

\section{Cultivation Aspects}

About $44 \%$ of the total estate sector coconut area lies in the Kurunegala district, $22 \%$ in Puttalam district and $11.5 \%$ in Gampaha district. The area cover $\mathrm{d}$ by these three districts forms the basis of the "coconut triangle", which has nearly $78 \%$ of the coconut estate sector area. As indicated in Table 1, coconut is primarily a small holder crop in Sri Lanka. Of the total area of 316,000 ha, $32.2 \%$ are in the Kurunegala district, $16.6 \%$ in Gampaha district and 9.7\% in Puttalam district. The average size of a small holding is 1 acre. According to a census carried out by the Department of Census and Statistics in 1982, about 90,000 ha $(225,000$ ac) or $29 \%$ of the area under smallholdings is made up of holdings less than 0.8 ha ( 2 ac.)

In order to formulate a strategy for the use of coconut wood, it is necessary to examine the varieties grown and the general age structure of the holdings. In Sri Lanka, there are three main varieties of coconut, namely tall (typica), dwarf (nana) and thambili (king coconut - aurantiaca). There are numerous forms of these varieties, which have been described by Wickramaratne (1987).

The commonest commercially grown variety - is the tall variety, typica. During the past 20 years or so, a limited amount of the dwarf $x$ tall (CRIC 65) hybrid has been planted, and the area under this hybrid has been estimated to be about 4,000 ha.

\section{Age Structure, Plant Density and Rotation}

The age structure of coconut plantations is important in determining the availability of wood for utilization. The actual economic life of a coconut palm is also an important consideration. It is of ten thought that the economic life span of a coconut tree is about 60 years. In Sri Lanka, high yielding palms much older than 60 years are not uncommon.

A study in 1980 indicated that in the coconut estate sector, 79.4\% of the palms are under 60 years of age. About $18.5 \%$ are 60 years and over. However, when the small holder sector is also considered, the overall pattern changes, and only $8.0 \%$ of the coconut are over 60 years old. The age structure of coconut is given in Table 2 (Perera, 1980).

The government operates a popular subsidy scheme for underplanting, where the new plants are planted about 6-8 years before the older trees are to be uprooted. In the estate sector $19.5 \%$ of the area is presently underplanted. Underplanting provides a regular output of trees. However, recent experience has shown that the small holders are reluctant to uproot the older palms in a systematic manner. The underplanting subsidy is paid in four instalments, and the final instalment (38\% of the total subsidy) is paid only if the specified number of older trees have, been removed. This condition has been imposed in order to ensure that the growth of the the underplantation is not adversely affected by shading from older trees. Consequently, only a very few small holders apply for the final subsidy instalment (Coconut Development Authority, 1981). As a result of the underplanting subsidy scherne, there is a gradual overcrowding of older palms thereby increasing the proportion of palms of 60 years and more. Any change, in the operation of the subsidy scherne is likely to influence the small holders in their perception of economies of prolonging the life of coconut trees and thereby influencing the availability of palms in the market. 
Table 2: Age Structure of Coconut in Sri Lanka

\begin{tabular}{|c|c|c|}
\hline Age Class (years) & \% Palms Population & Estimated Palm (X 10 $)$ \\
\hline $0-5$ & 7.56 & 6.39 \\
$5-15$ & 24.89 & 21.03 \\
$16-30$ & 21.47 & 18.14 \\
$31-45$ & 20.10 & 16.99 \\
$46-60$ & 17.93 & 15.15 \\
Over 60 & 8.05 & 6.80 \\
\hline & 100.00 & 84.50 \\
\hline
\end{tabular}

A comprehensive sample survey has been undertaken in Sri Lanka recently to assess the availability of timber and biomass fuel frorn coconut (see Goonatilake, 1985). In this survey, it was revealed that $98.5 \%$ of the trees belonged to the typica (tall) group and the balance either nana (dwarf) or CRIC 65 hybrids. All dwarf and hybrid plants were less than 30 years old. This survey also showed that the average density in the holdings was 57.4 palms/ac. In underplanted areas, the density of old trees was 49.8/ac whilst those of the young palms was 56.6/ac. From these data, it has been concluded that the average density of Sri Lankan coconut plantations is 57 trees/ac (141 trees/ha) which is slightly lower than the hitherto accepted density of 64 palms/ac (160 palms/ha). The rotation period ranged from 57 to 71 years, and 65 years appear to be a more representative age. This compares well with the annual replanting rate of $1.5 \%$ to $2.0 \%$ suggested for the industry (Liyanage, 1982).

\section{AVAILABILITY AND DEMAND OF WOOD IN SRI LANKA AND THE POSITION OF COCONUT}

In 1983, forestry contributed $1.7 \%$ to the Gross Domestic Product, or Rs 1.9 billion. The non-forest wood resources are primarily made up of tea, rubber, coconut, homestead gardens and areas classiiied as mixed trees and other perennial crops. If all resources are put together, the total value of wood production, harvesting and transport is around Rs 4.5 billion. The total area of non-forest wood and biornass resources is about 3.0 million ha or about $45 \%$ of the total area of Sri Lanka.

The present demand for industrial $\operatorname{logs}$ is $980,000 \mathrm{~m}^{3}$ sub per year. This is expected to increase upto about 1.4 million $\mathrm{n} 3 \mathrm{~b}$ during the period 1996-2000 and to 2.1 million $\mathrm{m}^{3}$ sub in 2011-2020 (Poyry, 1986).

It is reported that only about $20 \%$ of the available coconut wood of sawlog quality is used. This is mainly used for hand-hewn rafters. Considering the pmailable quantity of coconut wood, there is currently a large surplus of between $250,000 \mathrm{~m}^{3}$ to $300,000 \mathrm{~m}^{3}$ coconut wood per year. It is most likely that this surplus is used as fuel wood.

The availability and demand for industrial logs for the period 1986-2020 is given in Table 3. It would be seen that upto about 1990, Sri Lanka has surplus wood and need not depend on coconut wood. However, as demand increases with time, she would be obliged to increase the use of coconut wood. From Table 3, it would also be clear that Sri Lanka would face a shortage of industrial logs if not for coconut wood. 
Table 3: Availability and Demand for Industrial Logs ( $\mathrm{m}^{3}$ sub/year) 1986-2020

\begin{tabular}{|l|r|r|r|r|r|}
\hline & $1986-90$ & $1991-95$ & $1996-2000$ & $2001-10$ & $2011-20$ \\
\hline $\begin{array}{l}\text { Natural forests } \begin{array}{l}\text { Planted forest } \\
\text { Non-forest logs }\end{array} \\
\text { Coconut }\end{array}$ & 1,343 & 1,266 & 1,148 & 1,372 & 1,362 \\
Total availability & 1,704 & 1,592 & 1,486 & 1,715 & 1,729 \\
Demand & 1,050 & 1,230 & 1,390 & 1,680 & 2,050 \\
$\begin{array}{l}\text { Surplus (+) / Deficit (-) } \\
\text { if coconut is not used }\end{array}$ & +293 & +36 & -242 & -308 & -688 \\
\hline
\end{tabular}

Source: Poyry, 1986

A recent study has very clearly shown that the diminishing supply and increasing demand of wood can only be met by increasing the use of rubber and coconut wood. By the year 2000, the coconut wood use has to be increased by about $140 \%$ (from 3 the present level of $75,000 \mathrm{~m}^{3}$ sub/year to $191,000 \mathrm{~m}^{3}$ sub/year). If the use of coconut wood is not increased, the shortage of sawn timber will increase as follows (Poyry, 1986):

- 1990 by $15,000 \mathrm{~m}^{3}$ sub

- 1995 by $32,000 \mathrm{~m}^{3}$ sub

- 2000 by $43,000 \mathrm{~m}^{3}$ sub

Unless the use of coconut wood is developed, these deficits in the market will have to be met by imported wood. The projected development of coconut log use is given in Table 4.

Table 4: Development in the Utilization of Coconut Logs

\begin{tabular}{|c|c|}
\hline Period & Coconut log use ('000 $\mathrm{m}^{3}$ sub/year) \\
\hline $1986-1990$ & 102 \\
$1991-1995$ & 145 \\
$1996-2000$ & 174 \\
$2001-2010$ & 215 \\
$2011-2020$ & 235 \\
\hline
\end{tabular}

Source: Poyry, 1986

The demand development of wood upto the year 2020 has been projected by Poyry (1986). The demand for coconut $\log$ s for rafters has been estimated at a steady $60,000 \mathrm{~m}^{3}$ sub/year. The future supply of logs and sawn timber from coconut upto the year 2000 is given in Table 5. It is envisaged that the present level of supply of these two items will be increased by about $150 \%$ by the year 2000 . 
Table 5: Supply of Logs and Sawn Timber from Coconut Up to the Year 2000

\begin{tabular}{|c|c|c|}
\hline & $\begin{array}{c}\text { Logs } \\
\left(' 000 \mathrm{~m}^{3} \text { sub/year }\right)\end{array}$ & $\begin{array}{c}\text { Sawn Timber } \\
\left({ }^{3} 000 \mathrm{~m}^{3} / \text { Year }\right)\end{array}$ \\
\hline 1985 & 70 & 20 \\
1990 & 115 & 33 \\
1995 & 157 & 51 \\
2000 & 181 & 61 \\
\hline
\end{tabular}

\section{IMPORTANCE OF COCONUT AS A WOOD RESOURCE}

\section{Historical Aspects}

Timber has been traditionally used in construction work in Sri Lanka. For example, the Kandyan wooden architecture (circa $15^{\text {th }}$ century) has a distinct character of its own due to the wonderful timber architecture used. Insofar as Sri Lanka is concerned, coconut has been a 'traditional' wood and has been used extensively in building construction from ancient times. Coomaraswamy $(1956)$ and Karunaratne $(1971,1975)$ have given accounts on the dominant position of timber in construction in ancient Sri Lanka.

The use of coconut wood in medieval period in Sri Lanka is amply evident. "Sandesa" gives reference to coconut in the 15th century. The coconut palm in homesteads, is depicted in Degaldoruwa paintings (circa $18^{\text {th }}$ century). It is also well known that master carpenters in the $18^{\text {th }}$ and $19^{\text {th }}$ centuries used adze as the main tool for debarking, cutting and shaping wood. Currently, the adze is widely used for the preparation of coconut wood rafters, and this is an indication of the evolution of the practice of preparing adze-hewn coconut wood.

Coconut wood has been extensively used in building construction in ancient Sri Lanka. For example, the "Star Court" at Matara in the coastal belt of Southern Sri Lanka, built during the early dutch period (circa 1760's) has a considerable amount

Of coconut timber (Karunaratne, 1988).

In recent times, coconut is used almost exclusively for rafters. Architecturally, it is a very decorative, timber for balustrades and other decorative, work (Perera, 1985).

\section{Availability of Coconut Wood}

As indicated earlier, coconut can be classified as a "traditional" wood in the "non-forest wood resources" group. Coconut is a very important component of non-forest wood resources.

The results of a sample survey reported by Goonatilake (1985) show that about $75 \%$ of the coconut wood harvested by growers are sold while $21.4 \%$ are used by themselves (Table 6). However, about $78 \%$ of the coconut stumps are left unused (Table 7). In the estate sector, the stumps are normally removed when a tree is felled as a phytosanitory measure to prevent the breeding of the rhinoceros beetle (Oryctes rhinoceros). However, additional expenditure, will have to be incurred for this operation, and as a result, it is not a common practice in the small holder sector.

Goonatilake (1985) has also reported the yield of timber and fuel wood from coconut plantations (Table 8). It is seen that about $50 \mathrm{~m}^{3}$ sub of sawlogs could be extracted from a hectare, of mature plantation. 
Table 6: Use of Coconut Wood in 1984

\begin{tabular}{|l|r|r|}
\hline \multicolumn{1}{|c|}{ Use } & No of Palms & \multicolumn{2}{c|}{$\%$} \\
\hline Own use as fuelwood & 86 & 3.3 \\
Own use as timber & 555 & 21.4 \\
Given free & 18 & 0.7 \\
Sold to local people & 836 & 32.2 \\
Sold to outsider & 1,099 & 42.4 \\
Felled and left unused & 0 & 0.0 \\
Burnt & 0 & 0.0 \\
Other & 0 & 0.0 \\
\hline Total & 2,594 & 100.0 \\
\hline
\end{tabular}

Table 7: Use of Coconut Stump

\begin{tabular}{|lcr|}
\hline \multicolumn{2}{|l|}{ Own use as fuelwood : } & 3.2 \\
Given free to otgers & $:$ & 0.8 \\
Lef unused & $:$ & 77.7 \\
Burnt & $:$ & 18.3 \\
Sold & $:$ & 0.0 \\
\multicolumn{2}{r}{ (Sample response 80) } \\
\hline
\end{tabular}

Table 8: Estimated Average Yield of Timber and Fuelwood from Coconut (Volume in $\mathbf{~ m}^{3}$ sub)

\begin{tabular}{|l|r|r|}
\hline & Per Hectrare & Per Palm \\
\hline Stocking rate & 158.0 & 1.0 \\
Total wood volume & 101.1 & 0.634 \\
Stem volume & 82.0 & 0.516 \\
- saw log volume first 5 m above stump & 49.4 & 0.313 \\
- fuelwood volume & 32.6 & 0.203 \\
Stump volume & 19.6 & 0.124 \\
Total fuelwood volume & 51.6 & 0.327 \\
\hline (stump + stem fuelwood) Adapted from Goonatilake, 1985 \\
\hline
\end{tabular}

The availability of coconut wood largely depends on the rotation period. Goonatilake (1985 computed the removal rates of coconut palms upto the year 2020. These removal rates have been computed assuming a rotfition period of 70 years and using the data from the sample survey on the age structure of the coconut plantations. The area over 65 years has been estimated at $8 \%$ of the total area. About $2 \%$ is thought to be already removed, leaving only $6 \%$ of the total area for future removal. This area will be removed gradually at the following rates: $2 \%$ in 1988-1990, $1 \%$ each in 1991-1995 and 1996-2000. During the 36 year period betweer, 1985-2020, 51.2\% of the coconut area 
will be uprooted. This rate compares very favourably with the thboretical removal rate of about $1.5 \%$ suggested for the industry. Based on these assumptions, the coconut area to be uprooted up to 2020 is given in Table 9.

Table 9: Coconut Areas to be Uprooted: 1985-2020

\begin{tabular}{|c|r|r|r|r|r|}
\hline $\begin{array}{c}\text { Age Class } \\
\text { (Year) }\end{array}$ & \multicolumn{1}{|c|}{$\begin{array}{c}(\%) \\
-\end{array}$} & $\begin{array}{l}\text { Area } \\
\text { (Ha) }\end{array}$ & $\begin{array}{c}\text { Removal } \\
\text { Period }\end{array}$ & $\begin{array}{r}(\%) \text { to be } \\
\text { Removed }\end{array}$ & $\begin{array}{c}\text { Area to be } \\
\text { Removed } \\
\text { (ha) }\end{array}$ \\
\hline Over 65 & 8.0 & 33,520 & 1985 & 2.0 & 380 \\
$61-65$ & 6.0 & 25,140 & $1986-1990$ & 8.0 & 33,520 \\
$56-60$ & 6.0 & 25,140 & $1991-1995$ & 7.0 & 29,330 \\
$51-55$ & 6.0 & 25,140 & $1996-2000$ & 7.0 & 29,330 \\
$41-50$ & 13.3 & 55,725 & $2001-2010$ & 13.0 & 55,725 \\
$31-40$ & 13.9 & 58,240 & $2011-2020$ & 13.9 & 58,240 \\
\hline
\end{tabular}

Adapted from Goonatike, 1985

The district-wise annual production potential of timber and fuelwood from coconut plantations for the period 1985-1990 is given in Table 10. Similar computations have been made for different' periods upto 2020 (Table 11). On an average, about $600,000 \mathrm{~m}^{3}$ of coconut wood are available annually.

Table 10:- Annual Production Potential of Timber and Fuelwood from Coconut Plantations

\begin{tabular}{|l|r|r|r|r|r|}
\hline \multicolumn{1}{|c}{ District } & $\begin{array}{c}\text { Total Area } \\
(\text { ha })\end{array}$ & $\begin{array}{r}\text { Removal } \\
(\text { ha })\end{array}$ & $\begin{array}{c}\text { Sawlogs } \\
\left(\mathrm{m}^{3}\right)\end{array}$ & $\begin{array}{c}\text { Fuelwood } \\
\left(\mathrm{m}^{3}\right)\end{array}$ & \multicolumn{1}{c|}{$\begin{array}{c}\text { Total } \\
\left(\mathrm{m}^{3}\right)\end{array}$} \\
\hline Colombo & 9,737 & 162 & 7,985 & 8,340 & 16,325 \\
Gampaha & 64,164 & 1,065 & 52,617 & 54,960 & 107,577 \\
Kalutara & 12,327 & 205 & 10,109 & 10,559 & 20,668 \\
Kandy & 6,248 & 104 & 5,124 & 5,352 & 10,476 \\
Matale & 8,968 & 149 & 7,354 & 7,682 & 15,036 \\
Nuwara Eliya & 892 & 15 & 732 & 764 & 1,496 \\
Galle & 12,886 & 214 & 10,567 & 11,038 & 21,605 \\
Matara & 16,505 & 274 & 13,535 & 14,138 & 27,672 \\
Hambantota & 20,809 & 345 & 17,064 & 17,824 & 34,888 \\
Jaffna & 8,869 & 147 & 7,273 & 7,597 & 14,870 \\
Mannar & 1,342 & 22 & 1,100 & 1,150 & 2,250 \\
Vavuniya & 487 & 8 & 399 & 417 & 817 \\
Mulativu & 2,417 & 40 & 1,982 & 2,070 & 4,052 \\
Batticaloa & 4,044 & 67 & 3,316 & 3,464 & 6,780 \\
Ampara & 3,167 & 53 & 2,597 & 2,713 & 5,310 \\
\hline
\end{tabular}




\begin{tabular}{|l|r|r|r|r|r|}
\hline Trincomalee & 1,936 & 32 & 1,588 & 1,658 & 3,246 \\
Kurunegala & 147,551 & 2,449 & 120,998 & 126,386 & 247,384 \\
Puttalam & 53,182 & 883 & 43,611 & 45,554 & 89,165 \\
Anuradhapura & 4,304 & 71 & 3,529 & 3,687 & 7,216 \\
Polonnaruwa & 2,454 & 41 & 2,012 & 2,102 & 4,114 \\
Badulla & 609 & 10 & 499 & 522 & 1,021 \\
Moneragala & 3,694 & 61 & 3,029 & 3,164 & 6,193 \\
Ratnapura & 11,782 & 196 & 9,662 & 10,092 & 19,754 \\
Kegalle & 20,820 & 346 & 17,073 & 17,834 & 34,907 \\
\hline \multicolumn{1}{|c|}{ T o t a 1 } & $\mathbf{4 1 9 , 1 9 5}$ & $\mathbf{6 , 9 5 9}$ & $\mathbf{3 4 3 , 7 5 5}$ & $\mathbf{3 5 9 , 0 6 7}$ & $\mathbf{7 0 2 , 8 2 2}$ \\
\hline
\end{tabular}

Table 11:- Production Potential of Timber and Fuelwood From Coconut Plantations 1985-2020

\begin{tabular}{|c|r|r|r|r|}
\hline Period & Removal (ha) & $\begin{array}{c}\text { Sawlogs } \\
\left({ }^{\circ} 000 \mathrm{~m}^{3}\right)\end{array}$ & $\begin{array}{c}\text { Fuelwood ('000 } \\
\left.\mathrm{m}^{3}\right)\end{array}$ & $\begin{array}{c}\text { Total } \\
\left({ }^{\circ} 000 \mathrm{~m}^{3}\right)\end{array}$ \\
\hline $1986-1990$ & 33,520 & $1,655.9$ & $1,929.6$ & $3,385.5$ \\
$1991-1995$ & 29,330 & $1,448.9$ & $1,513.4$ & $2,962.3$ \\
$1996-2010$ & 29,330 & $1,448.9$ & $1,513.4$ & $2,962.3$ \\
$2001-2010$ & 55,725 & $2,752.8$ & $2,875.4$ & $5,628.2$ \\
$2011-2020$ & 58,240 & $2,877.0$ & $3,005.2$ & $5,882.2$ \\
\hline & 206,145 & $10,183.5$ & $10,637.0$ & $20,820.5$ \\
\hline
\end{tabular}

\section{CONSTRAINTS IN THE DEVELOPMENT OF COCONUT WOOD-BASED INDUSTRIES}

The peculiar characteristics of coconut wood restrict its large scale industrial use. The density variation within a palm is very wide. The pith in the palm stem is unsuitable for timber. These drawbacks do not allow the production of large dimension timber of uniform density range.

The peripheral areas of mature trunk is very hard. The tracheids too are extremely hard, and the parenchymatous cells contain above-normal quantities of silica. These special characteristics warrant the use of special cutting blades. Normally, saw-teeth have to be specially hardened using tungsten carbide or stellite, both of which are expensive. The immense heat produced in the process of using machine-driven saws often make saw teeth blunt, needing regular attention. Work carried out in Sri Lanka has shown that for every sharpening given to tungsten carbidetipped saw, a stellite-tipped saw will be sharpened five times and retipped and ground once (Francis and Bergseng, 1984 a).

The problems associated with curing high-moisture containing coconut wood are also common. The common defects are bow (in low-density badly stacked wood), cup (again in low-density wood) and stain (Embogama, 1987). However, these are not insurmountable, and it requires only education, training and experience to learn proper drying methods. 
Francis and Bergseng (1984 a) carried out a study Sri Lanka and recomended a design for a coconut sawmill. Their financial analysis indicated that the cost of the mill could be recovered within a few years. However, the initial capital required at that tirne for the machinery alone was about US\$ 500,000, and is beyond the means of most enterpreneurs. In view of this high capital requirement, establishment of coconut sawmills has not attracted much attention. However, a recent study of Poyry (1986) indicates that investment in new coconut sawmills may not be financially viable, considering the cost and price rellations existed at th.at time in Sri Lanka. Under the circumstances, it is likely that, at least in the imn-tediate future, manual methods will continue to be used for converting cocoilut wood into the item of most deTnand, namely rafters.

\section{CURRENT TRENDS IN COCONUT WOOD UTILIZATION IN SRI LANKA}

The development of coconut wood-based industries in Sn Lanka has been slow owing to numerous constraints, some of which are desc.-ibed elsewhere. Traditionally, coconut wood has been used in the construction of buildings, particularly dwelling houses. The most common uses of coconut are roof trusses (medium density), rafters (high density) and roof shingles (medium high density). In addition, a considerable amount of flooring (high density) and wall panelling (medium and high density) are also made. Coconut wood is also used on a very limited scale for the manufacture of furniture and artifacts.

\section{Timber}

Until about the early 1980's, almost the entire coconut wood processing was manual. Large scale handhewn rafter manufacture is not uncommon in the main coconut growing areas.

\section{Mechanized Wood Processing}

As indicated earlier, previous attempts to install sawmills for coconut wood were unsuccessful, primarily owing to the heavy capital outlay required. In the early 1980's the United Nations Industrial Development Organization (UNIDO) carried out a study in Sri Lanka and recommended that a new sawmill be installed to complement the facilities of Borwood Ltd, which was operating on treated rubber wood, to enable them to undertake coconut wood utilization. The UNIDO also provided assistance with a saw doctor and other technical inputs (see Bergseng, 1984). However, these proposals have not been implemented.

In the mid 80's, the State Timber Corporation of Sri Lanka (STC) began mechanized processing of coconut wood using a sawmill gifted to the Government of Sri Lanka for processing the cyclone-felled palms in Eastern Province. After the operations in the Eastern Province were completed by the Coconut Development Authority of Sri Lanka, the sawmill was relocated at Nattandiya in the North Western Province in the heart of the coconut growing area. The STC also encoaraged several private enterpreneurs to commence mechanized processing of coconut wood. Assistance was provided to these mills for stellite-tipping their saw teeth, and the sawn timber was taken by the STC. In addition to the STC sawmill, currently there are about 10 other mills engaged in coconut wood processing. However, at the present moment, the work is disrupted owing to the sudden increase in the cost of stellite-tipping. Hopefully, the STC will absorb at least a part of this increase so that the private mills could continue the operations.

Presently, the STC annually processes about $1,200 \mathrm{~m}^{3}$ of coconut logs. About $70 \%$ of this is used for the manufacture of mechanical-sawn rafters. The balance is used for the manufacture of wall-panelling, balustrades and furniture. Coconut wood also offers the possibility of reasonably long lengths of scantling, say 5 meters, which allow construction of trusses. Coconut has an 
estimated stress rating of F8 for outerwood, thereby allowing the designs as per British Standards 5,268 to be used for tiled roofs (Francis and Bergseng, $1984 \mathrm{~b}$ ).

Mechanically-sawn rafters and other roof members have become popular in the construction industry. The uniform thickness of the rafters enables easier handling, and the carpenters prefer them to hand-hewn rafters.

Facilities for curing and treating coconut wood are available with the STC.

\section{Drying and Preservation of Coconut Wood:}

Coconut timber contains more moisture than most other woods. Often $400 \%$ moisture has been encountered. The presence of high moisture content requires careful drying. Work done in Sri Lanka has indicated that coconut wood has fibre saturation point at approximately $21-23 \%$ moisture content. Low density coconut wood, which has a high moisture content, tends to collapse during early stages of drying (Mohanadas and Ratnayake, 1984).

The STC has a solar drier for sawn coconut timber, but the timber has to be stacked properly to avoid warping etc. Drying in a steam kiln appears to be the most, acceptable method to avoid defects. In a steam kiln, a week's curing is adequate (Embogama, 1988).

Several preservatives, both water-based and oil- based, are available for treating coconut wood. At the STC, the choice of the preservating agent depends on the ultimate use of the timber. For example, copperchrome-arsenate (CCA) cannot be used on sawn timber if they are to be used for wood panelling as CCA gives a colour to the wood, rendering it unsatisfactory for final polishing. Wood consigned for poles and fence posts is treated with creosote. Timber for purlins, trusses, joists and other structural members can be treated with boron. In Sri Lanka, the treatment of wood is carried out using nonpressure processes such as dipping and soaking and steeping.

\section{Development of Coconut Wood Promming:}

The income generated by the STC on coconut wood processing has been increasing gradually. The income derived in 1986 has been about SLRs 2 million and in 1987 about SLRs 4.0 million. The projected income for 1988 is SLRs 5 million (US \$ 1= Sri Lanka Rs 30).

Coconut wood processing by the private sector too is on the increase. Although accurate statistics are not available, the number of carpentry shops dealing with coconut wood has increased appreciably during the past few years.

\section{Furniture}

Coconut wood has been used as a source of timber for furniture for a long time in Sri Lanka. It is not uncommon to see coconut wood in antique furniture items. However, its use has been rather limited, perhaps due to the high cost of processing.

In the recent times, the State Timber Corporation pioneered the use of coconut wood in general furniture manufacture. The publicity given to this venture, and the availability of coconut-based furniture at affordable prices have created an awareness and interest in the general public, who have hitherto generally not considered coconut as a possible candidate for furniture manufacture. The interest generated, and the availability of mechanized processing have resulted in several small to mediumsized furniture manufacturing concerns using coconut wood. The private 
sector now produces a range of coconut wood-based furniture, both for the regular and luxury markets, and the increasing demand for these products augurs well for the prospects of increasing the use of coconut wood in this sector.

\section{Coconut Wood in the Construction Industry}

A novel technique of using coconut timber for reinforcement in concrete has been described by Kulasinghe (1984). This reinforcement can either be in the form of strips of small sections embedded in the concrete or larger sections, banded to the top and the bottom of a concrete section. Rafters and reepers of sizes varying from 4" x 2", 5' x 2" and 6" x 2" have been made by this method using 2" x 1" coconut timber. Figs. 1 (a) and 1 (b) show the cross sections of such coconut/concrete members. These members allow economical construction of roofs and also give a neat and attractive appearance.

Kulasinghe (1984) has also shown that coconut timber can be embedded in concrete to reinforce the latter. A cross section of a lintel reinforced using two pieces of coconut timber of $1 " \mathrm{x}$ $1 / 2$ " is given in Fig. 1(c). However, when coconut timber is embedd steps should be taken to avoid the normal shrinkage ol wood and the consequent loss of bond. This can be conveniently avoided by coating the timber first with water-proofing material.

At the National Engineering Research and Development Centre in Sri Lanka, large span (40 feet) roof trusses made of coconut wood have been tested and found to be economical. Two methods of construction suggested are (a) ordinary Howe type roof trusses, and (b) Vierendeel type roof trusses (Kulasinge, 1984).

In the recent past, use of coconut wood in house construction has increased (Samarasekera, 1988). Coconut makes the construction attractive and natural, and being an uncommon wood for purposes other than rafters, enhances the value of construction. In addition to the rafters and purlins, wall plates, ridge plates and ventillating grills made of coconut timber are not uncommon. Demand for such items is on the increase.

A notable departure from the traditional use of coconut wood is its use in supporting columns. The debarked logs are thoroughly dried and iron rods driven through the pith, which is then impregnated with wood preservative. Colourless wood preservative is used externally. Such columns should be kept off the floor with a concretepad to avoid termite damage. An alternative way of construction of column is to use coconut timber to encase concrete columns. After drying the log, it is split in two, pith removed and the two halves are thoroughly impregnated with wood preservatives. The two halves are then bolted together around the concrete column and the bolt holes plugged with same timber. 


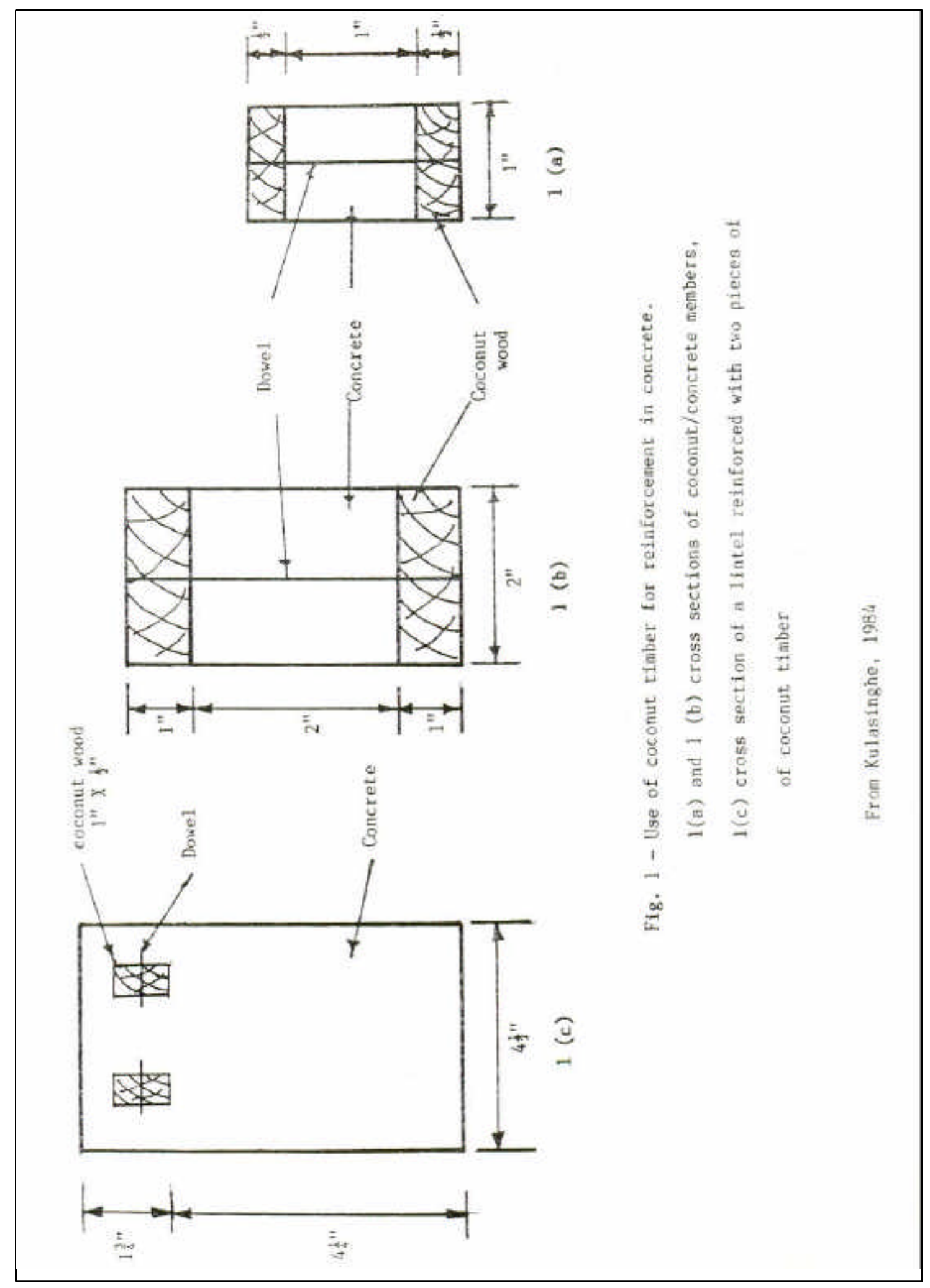




\section{Coconut Wood as a Source of Fuel}

Coconut wood is well known as a fuelwood. In fact, much of the available coconut wood in Sri Lanka is yet used as fuelwood, particularly in brick and tile kilns.

The chemical composition of coconut wood is similar to other woods, with $50 \%$ carbon, $6.2 \%$ hydrogen and $43.8 \%$ oxygen. Thus thermal value is also similar to other woods, and averages $8,500 \mathrm{BTU} / \mathrm{lb}$ (oven dry basis). Coconut wood has been identified as a possible source of fuel for small-scale power generation (Groom and Associates, 1982).

In Sri Lanka, coconut logs are used extensively in both brick and tile kilns. In the manufacture of bricks, an ad hoc kiln is made everytime when bricks are to be cured, using the clay blocks that are to be cured as bricks. However, tile kilns are permanent ones. The use of coconut wood in tile kilns is less than that in brick kilns because of the difficulties encountered in handling coconut logs, in tile kilns.

Traditionally, coconut logs are cut into pieces of about 1 metre in length and costs about US\$ 0.50 per piece delivered to the kiln. Presently, it appears to be cheaper than other fuelwood. About 7 to 8 pieces are required to cure 1,000 bricks.

As a fuelwood, coconut wood has several attractions for brick and tile industries. Firstly, it is relatively cheap. Secondly, it is available in areas where brick and tile industries are concentrated. Thirdly, coconut wood does not generate intense heat as does some other hard wood types. In fact, the moderate heat generated by Coconut wood is ideal for curing clay. It is perhaps because burning fuel of high moisture content moderates temperature.

The National Engineering Research of Sri Lanka has rnanufactured a range of gasifiers, some of which could be used in copra and desiccated coconut manufacture. These gasifiers are designed to use coconut stem effectively (Kulasinghe, 1988).

\section{Other Uses of Coconut Stem}

Coconut timber can be sawn into planks varying in thickness from about $1 / 4$ " to 1 The hardwood portions can be separated and laminated to produce structural members of various sizes. This process reduces the waste involved in sawing larger rectangular sections from the log itself (Kulasinghe, 1984). Manufacture of "ligno-plasticized" wood from coconut wood has already been demonstrated (Silva, 1971).

In Sri Lanka, wall panelling and balustrades made of coconut wood are becoming increasingly popular. The output of these products by the State Timber Corporation of Sri Lanka is gradually increasing (Embogama 1985).

The Ceylon Institute of Scientific and Industrial Research (CISIR) conducted research and demonstrated the feasibility of manufacture of paper board, fibre board and particle board from the softer portions of the coconut stem (Silva, 1971). However, the technoeconomic aspects of these processes need further study.

With the increasing mechanical sawing of coconut logs, the demand for coconut wood saw dust by the rural populace for cooking stoves is increasing. It is claimed that coconut wood saw dust gives ideal heat for cooking. This aspects needs further investigation. Coconut wood saw dust is also in demand for tile and brick kilns. 


\section{REFERENCES}

Bergseng, K. (1984) Technical Report: Coconut wood sawmilling and saw doctoring. Report DPIID/SER.A/549 of the Project DP/SRL/79/053, UNIDO, Vienna.

Coomaraswamy, Ananda K (1956) Mediaeval Sinhalese Art. Pantheon Books, New York, 344 pp.

Coconut Development Authority (1981) Survey of subsidy schemes operated by the Coconut Cultivation Board, Colombo.

Embogama, N. B. (1985) Sri Lanka turns to coconut lumber. Coconis 21: 4

Embogama, N. B. (1987) Unpublished data.

Embogama, N. B. (1988) pers. com.

Francis, C. R. \& K Bergseng (1984 a) Technical Report: Sawing small coconut logs. Report No. DP/ID/SER.A /528 of the Project DP/SRL/79/053, UNIDO, Vienna.

Francis, C R \& K Bergseng (1984b) Terminal Report: Research and Development for the utilization of rubber wood and coconut wood. Report DP/ID/SER.B/479 of the Project DP/SRL/79/053, UNIDO, Vienna.

Goonatilake, P. C. L. (1985) Assessment of non-forest wood resources in Sri Lanka for the period 19852020. Forest Resources Development Project, Ministry of Lands and Land Development, Colombo. 189 pp.

Groom, J. G \& Associates (1982) Small-scale power generation using coconut wood and other wood wastes. Food \& Agriculture Organization Report FO: MISC/82/27, 66 pp.

Karunaratne, L. K. (1971) Architecture in wood. Ancient Ceylon 1: 121-126

Karuratne, L. K. (1975) Wooden architecture of Sri Lanka. The Ceylon Historical Journal XXIV: (1-4) 174-185.

Karuratne, L. K. (1988) pers. com.

Kulasinghe, A. N. S. (1984) The use of coconut timber in engineering structures. In Timber Technology ed. A Jayatillake, University of Moratuwa Press, Sri Lanka. 130-142.

Kulasinghe, A. N. S. (1988) pers. com.

Liyanage, D. V. (1982) Improvement of coconut seednut and seedling selection. Report No. 1 of the Consultant in Breeding. Coconut Development Authority of Sri Lanka, Colombo.

Mohanadas, S \& P. A. N Ratnayake (1984) Treatment of coconut timber. In Timber Technology ed. A Jayatillake, University of Moratuwa Press, Sri Lanka. 182-185.

Perera, D (1985) Timber as a building material in Sri Lankan architecture. In Timber Technology ed. A Jayatillake, University of Moratuwa Press, Sri Lanka. 168-172.

Perera, U. V. H. (1980) Replanting in coconut. Internal Report of the Coconut Development Authority, Colombo. 
Poyry, J. (1986) Forestry Master Plan for Sri Lanka. Main Report and Executive Summary. Jaakko Poyry International Oy, Helsinki. 149 pp.

Samarasekera, J. (1988) pers. com.

Silva, S. S. (1971) Industrial utilization of coconut wood. Report No. 1404 of the Ceylon Institute for Scientific and Industrial Research Colombo. 2pp.

Tillakaratne, S \& U. V. H. Perera (1981) An economic study of the coconut industry in Sri Lanka. Monograph of the Peoples Bank Research Department, Colombo.

Wickramaratne, M. R. T. (1986) Know your nuts - Coconut varieties in Sri Lanka. Coconut Bulletin $3(2) ; 32-34$.

\section{ACKNOWLEDGEMENTS}

The assistance rendered by Mr. N.B. Embogama of the State Timber Corporation of Sri Lanka, Dr. J. Samarasekera, Architect, Mr. L.K. Karunaratne, Architect and Dr. A.N.S. Kulasinghe, Chairman of the National Engineering Research and Development Centre of Sri Lanka is gratefully acknowledged. 